The female labor force participation decision has often been conceptualized inThrar pre-published version the choice between market work and housework. In this framework the opportunity cost of market employment is the value of the reduced time available for household work. Factors that determine the terms of the trade-off, such as the presence of young children and the woman's potential wage rate, are expected to affect her probability of participating in the labor market. These predictions have been the subject of a substantial body of research and they are largely borne out by empirical evidence (e.g., Mincer 1962; Bowen and Finegan 1969; Gronau 1973; Smith and Ward 1985). Economists, however, have paid much less attention to the choice between self-produced domestic work and market-procured domestic work.

Domestic duties need not be performed by the woman herself: automated household appliances and household servants are substitutes readily available from the market. The availability of these (imperfect) substitutes alters women's labor force participation decision. For example, the spread of electrical household appliances is often mentioned as one factor behind the secular growth in the female labor force, although little empirical research has been done to test this hypothesis. Similarly the use of a domestic servant is expected to increase the likelihood of female labor force participation. This paper uses a data set from Hong Kong to examine the hypothesis that women's supply of market work and their demand for domestic servants are joint decisions. Contrary to Veblen (1953), who takes the use of domestics as one of the hallmarks of the leisure class, I find that women who hire servants have a substantially higher conditional probability of labor force participation than women who do not. The approach also gives a richer description of the division of labor within the household. For example it will be shown that the negative relationship between child care and labor force participation does not hold in households that employ domestic help.

Reliable data concerning the use of domestic helpers are hard to come by. ${ }^{1}$ Many couples have the experience of hiring part-time baby-sitters for an evening. The "foreign nannies" episode in the Clinton administration's nomination for an Attorney General

1 Stigler's (1946) study of domestic servants in the United States is almost half a century old, and it does not cover the relationship between the use of domestics and female labor supply. 
highlighted many professional women's reliance on domestic help. In Hong Kong the weekly gathering of Filipino maids has become a permanent scene in the city. The number of foreign domestic helpers in Hong Kong rose from 1,350 in 1975 to 11,031 in 1980, and to 70,335 in 1990 (Ho et al. 1991). Thus, in 1990, roughly 4.5 percent of the households hired full-time foreign domestic helpers. This percentage would be greater if part-time helpers and local and Chinese servants were included.

In a closed economy, a general rise in women's market productivity would increase female labor force participation, thereby increasing the demand for market-procured household work. However, if a woman has a comparative advantage in managing her own household and if there are no significant economies of scale to household work, the rise in market productivity would also reduce the supply of domestic helpers. It is, then, not surprising that industrialization in the U.S. and in Britain had been accompanied by a decline in the domestic servants industry (Horn 1975; Katzman 1978). The recent growth in the market for domestic work is partly a result of the increasing international mobility of labor. ${ }^{2}$ In 1976 , before the systematic import of foreign domestic helpers into Hong Kong, there were approximately 18,000 domestic servants living in their employers' households. In 1986 the number increased to 36,000. During the same period the proportion of domestic servants who were of foreign origin rose from 2 percent to 71 percent (author's calculation). The wage differential between women in Hong Kong and, say, women in the Philippines allows mutually beneficial division of labor: although a Hong Kong woman may have absolute advantage in managing her own household, she may have comparative disadvantage vis-a-vis a low-wage Filipino maid. The possibility of hiring outsiders to perform household work introduces a previously unexplored margin in the analysis of the time allocation problem. The following section discusses the interrelation between the demand for domestic help and the supply of market work.

\section{Theoretical Considerations}

Suppose a woman may allocate her time between three activities: housework, market

2 It is no coincidence that the servants of Ms. Baird and Judge Wood, the Attorney General candidates, were both immigrants to the U.S. 
work, and leisure. If housework done by the woman herself and housework done by hired servants are perfect substitutes, and if market-procured domestic service is perfectly divisible, the woman will purchase domestic service whenever her market wage exceeds the price per unit time of domestic service. Given any wage rate, the demand for domestic service and the supply of market work will then be separate decisions. However neither of the underlying assumptions behind this conclusion is plausible. It is unlikely that a woman will regard one hour of child care by herself as equivalent to one hour of child care by her servant. If women attach intrinsic utility or disutility to the time spent on housework, market-procured domestic service will not be a perfect substitute for self-produced domestic work (Pollak and Wachter 1975). Market-procured domestic service is not perfectly divisible either. In Hong Kong, for example, employers of foreign servants are required by law to pay their servants full-time and provide them with accommodation. This introduces a fixed cost component to the decision to hire domestic servants. In any case the data used here do not provide information about part-time domestic help. Thus the demand for domestic service will be modeled as a discrete choice.

With three different activities, the substitution and complementarity possibilities between alternative uses of time are too numerous to yield any definite predictions. Nevertheless some basic insights emerge from a simplified model. Let the time required to do housework be $D$. I assume $D$ to be fixed for a given household. ${ }^{3}$ For a woman who hires a servant, she pays a cost of $P$ and her time endowment is $T$. For a woman who does not hire domestic help, her time endowment would be $T-D$. The time endowment is to be allocated between market work and leisure. Only consumption and leisure enter directly into the woman's utility function. In effect, this simplified model assumes housework is a fixed cost that can be overcome by market-procured domestic help. ${ }^{4}$

3 The time required to do housework may still vary across households. For example, families with young children may be associated with a high $D$.

4 For related models, see Heckman (1974), on the effects of child care programs, and Cogan (1981), on the fixed costs of employment. 
Figure 1 illustrates the effect of a market for domestic servants on the female labor supply decision. Panel (a) shows the case when $w$, the woman's potential wage rate, is equal to $P / D$, the cost per unit time of domestic service. The relevant budget constraint without a domestic helper is $C A S$, where $S$ is equal to $T-D$ and the vertical distance $S A$ is equal to the woman's non-wage income, $A$. In the figure the slope of the indifference curve $U_{0}$ at $A$ is steeper than the slope of the budget line: the woman will not participate in the labor market. If the woman hires a servant, the relevant budget constraint becomes $C B T$. The vertical distance $T B$ is equal to $A-P$. Notice that point $B$ is associated with less consumption and more leisure compared to point $A$. If both consumption and leisure are normal goods, the indifference curve at $B$ will have a flatter slope than that at $A$. This implies the woman will have a lower reservation wage for entering the labor force. For example, if the indifference curve $U_{1}$ is tangent to the line segment $A B$, as shown in the figure, the woman can increase her utility by hiring a servant and entering the labor force at the same time. The availability of a market for domestic service then increases labor force participation even when the cost of a servant is the same as the woman's time cost.

Panel (b) of Figure 1 illustrates the case when $w>P / D$. The budget line with a servant, $C^{\prime} B T$, dominates the budget line without a servant, $C A S$. If both leisure and consumption are normal goods, the slope of the indifference curve at $B$ will be flatter than that at $A$. Again, the woman is more likely to participate in the labor market when she uses market-procured domestic help. The same principle applies to panel (c), which shows the case when $w<P / D$. Even though the woman has a lower time cost than the servant, she may still benefit by hiring a servant and entering the labor force. This is possible because at point $A$, the marginal rate of substitution between leisure and consumption is strictly greater than the wage rate. To be sure, in the case shown in panel (c), the woman may decide not to hire a servant and stay out of the labor force when $P$ is sufficiently large.

Figure 1 demonstrates that having a domestic servant will lower the reservation wage for entering the labor force. Thus the presence of domestic servants and labor 
force participation status will be positively related. Women who have servants are more likely to be in the labor force, and vice versa. This hypothesis will be examined with data from Hong Kong.

A less obvious conclusion of the model emerges from Figure 2. The figure shows the indifference curves and budget constraints of a woman who would choose to obtain market employment even in the absence of domestic help. If $w=P / D$ (panel a), the availability of a domestic helper does not make her (strictly) better off. If $w<P / D$ (panel c), hiring a domestic helper will make her (strictly) worse off. ${ }^{5}$ Comparing the corresponding panels of Figures 1 and 2, one can see that, holding wage rate constant, a market for domestic service is more likely to benefit women who would otherwise stay out of the labor force than women who would otherwise choose market employment. In other words, women who would otherwise choose market employment are less likely to hire servants when such domestic help becomes available in the market. ${ }^{6}$ If panel data exist for a period in which there was an exogenous increase in supply of domestic helpers (due to changes in immigration policies, say), one will predict that women workers would be less likely to hire servants than housewives would when the supply of servants increased. Unfortunately, since census data in Hong Kong only record the joint choice of domestic help and labor market participation, this hypothesis cannot be tested here.

Another implication of the model concerns children and labor force participation. The presence of young children in a family will increase the amount of housework, $D$, to be done. For a woman who does not hire domestic help, her time endowment, $T-D$, will be relatively low. A low time endowment, holding non-wage income unchanged, will increase the reservation wage for labor force participation. For a woman who hires domestic help, on the other hand, her time endowment will be $T$ since all housework is performed by the servant. Holding non-wage income constant, the presence of young

5 Since consumption and leisure are both normal goods, the tangency point between $U_{1}$ and $C^{\prime} B$ is to the south-west of the tangency between $U_{0}$ and $C A$. Therefore $U_{1}$ represents a lower utility level than $U_{0}$.

6 This conclusion relies on the assumption that utility depends only on consumption and leisure. If market work and housework generate fatigue, or if there exist other substitutability or complementarity relations between the two activities, the conclusion need not hold in general. Another consideration is that women with different labor market experience tend to accumulate different sets of skills. 
children will not increase her reservation wage for labor force participation. ${ }^{7}$ Thus, while the presence of young children tends to reduce female labor participation among women who do not employ domestic servants, this relationship need not hold for women who employ domestic servants.

\section{Description of the Data}

The Labour Department of Hong Kong requires employers of foreign domestic helpers to provide them with accommodation. It is also common practice that local and Chinese full-time servants live with their employers. According to the 1986 Population ByCensus records, for example, 63 percent of those whose occupation was "domestic amah or baby-sitter" lived with their employers (author's calculation). This offers a unique opportunity to use Census data to reveal information about the use of domestic help within households. If the servant stayed at the employer's household at the "reference night" (3 am. in the morning on a particular date), the use of domestic help in a household can be correctly coded. It should be noted, however, that this method is unlikely to record the use of part-time domestic helpers or the use of servants who live outside the employer's household.

The data used here is a one percent random sample of the Hong Kong 1986 Population By-Census. I selected records of married women who were either the head of a domestic household or the head's spouse. This resulted in a sample of 9,783 women. If there was a servant living at the woman's household at the "reference night," the dummy variable SERVANT was coded 1.8 The age and number of children living with each woman were also recorded. The variable HINCOME was constructed by subtracting each woman's employment earnings from her household income. Relevant sample statistics are presented in Table 1.

7 The non-wage income of a woman who hires domestic help is $A-P$. If $P$, the price of domestic service, is higher when the family has children, the income effect will lower the reservation wage for labor force participation, making it even more likely that the woman joins the labor force. In Hong Kong, however, the Labour Department fixes a minimum wage for foreign domestic helpers. This minimum wage is much higher than the foreign domestic helpers' alternative wage, so the price of domestic service will not rise with the amount of domestic work.

8 The SERVANT variable was treated as a dummy variable even though there were 28 women with more than one servant. 
Table 2 shows the contingency table of labor force participation status and the use of domestic helpers. Pearson's chi-squared test for independence yields a test statistic of 32.56 with one degree of freedom. The critical chi-squared value at the one percent level of significance is 6.63. The raw numbers indicate that women who participated in the labor force were more likely to have domestic helpers, and that women who had domestic helpers were more likely to be in the labor force. The empirical relationship between these two decisions will be subject to closer scrutiny in the next section.

Before I turn to the econometric models, it is of independent interest to take a closer look at the characteristics of the domestic servants. Using the census records, I selected a sample of 358 domestic servants who lived in their employers' households at the "reference night." 9 Of these 358 servants, 97 percent were female. Their average age was 40, with a standard deviation of 16 years. Average monthly income was $\$ 1,895$ (s.d.=\$658). ${ }^{10}$ This compares with the average monthly income of $\$ 2,789$ for all employed women in 1986 (Lui and Suen, forthcoming). Perhaps the most striking feature of the sample is the proportion of foreign workers and immigrants. Only 3 percent of the sample of servants were born locally in Hong Kong. 26 percent came from China or Macau, and 71 percent were born elsewhere, mainly the Philippines and (to a lesser extent) Thailand. This group of foreign domestic helpers were highly educated: 22 percent had university degrees. The local folklore about the graduate Filipino maid turns out not to be a myth. ${ }^{11}$

\section{Empirical Estimation}

The positive association between the use of domestic help and labor market participation shown in Table 2 above could be due to confounding factors. For example, women who face high market wage rates are more likely to hire domestic help and enter the labor force. On the other hand, women with high non-wage income may shun both market

\footnotetext{
9 Some of the servants here did not work for the households in the sample of women.

10 All dollars figures are denominated in Hong Kong Dollars. At the time the exchange rate was roughly one U.S. Dollar to 7.8 H.K. Dollars.

11 The high level of education reflects the effect of minimum wage. Employers tend to select overqualified workers when the wage rate is above the market-clearing level.
} 
work and housework. One way to control for such factors is to estimate a bivariate system of equations using the exogenous variables on the right hand side. These exogenous variables include the price of servants' time, a woman's wage offer, other household income, and the demographic variables. In a cross section, variations in servants' pay probably reflect variations in their quality and intensity of work rather than differences in price faced by employers. If price information in the market for domestic helpers is reasonable good (and there are a lot of specialized employment agencies in Hong Kong), one can treat the price of domestics as a constant in a cross sectional analysis. In the absence of unobserved taste heterogeneity, then, the estimated correlation coefficient of the error terms in a bivariate probit regression can indicate the interdependence of the two decisions, holding other factors fixed. In the presence of unobserved taste heterogeneity, however, the estimated relationship cannot identify the underlying taste parameters (see Rosenzweig and Wolpin 1980). The bivariate regression will then only give a compact way of describing the data.

I assume a woman's demand for domestic help and her supply of market work depend on the following set of factors: her market wage rate, her non-wage income, age, and the number of children in the family. Market wage rate is unobservable for women who choose not to work. If the wage rate is assumed to be a function of age and education (and their squares), it can be estimated by a selectivity-bias corrected regression (Heckman 1979). ${ }^{12}$ Alternatively the education variables can be substituted directly into the reduced form bivariate probit regression. The results of both approaches are displayed in Table 3.

The first pair of equations in the second and third column are the probit regressions using the predicted wage as independent variable, while the second pair of equations use education instead of predicted wage. With the exception of the age variables, the coefficients of other variables are quite stable across the different specifications. The effect of age on labor force participation, however, is much reduced in strength when

\footnotetext{
12 More specifically, the logarithm of wage was regressed on age, age squared, education, education squared, and the inverse Mills ratio. The estimated coefficients were then used to construct the predicted wage, LNWAGE_HAT.
} 
wages are controlled.

Most of the variables in Table 3 are of the expected signs and are statistically significant. At the sample mean, a one standard deviation increase in the predicted wage would raise the probability of labor force participation from .46 to .54, while a one standard deviation increase in HINCOME would lower the probability to .41. For a woman with no child between 0 and 3 years old, her probability of entering the labor force is estimated to be .51. For a woman with such a child, this probability drops to .31. The direction of the predicted effects accords well with studies in the U.S. (e.g., Killingsworth and Heckman 1986).

Turning to the equation for SERVANT, the woman's (predicted) wage is found to have a significant positive effect on her use of domestic help. The probability of hiring a servant increases by .020 if LNWAGE_HAT is one standard deviation above the mean. Clearly women with higher time costs were significantly more likely to hire domestic help. Domestic service also seems to be a normal good: a one standard deviation increase in non-wage income raises the probability of having a servant by .008 . Child care is another important consideration in the decision to hire domestic help. Women with a child between 0 and 3 years old had a .009 higher probability of hiring a servant than women with no such child. Finally the age variables are not statistically significant: life-cycle or cohort effects did not play an important role in the demand for servants.

The variable RHO in Table 3 denotes the correlation coefficient between the error terms of the bivariate probit regression. This correlation coefficient is estimated to be .21 and is statistically significant. From this coefficient, one can calculate how participation status affects the conditional probability of hiring servants. ${ }^{13}$ The conditional probability of labor force participation is calculated to be 22 percentage points higher for women who had servants than for women who had no servants. Conversely, labor force participation also has a positive effect on the use of domestic help. At the sample mean, women who

\footnotetext{
13 Let $e_{p}$ and $\beta_{p}$ be the error term and the estimated coefficients for the participation equation. Similarly define $e_{s}$ and $\beta_{s}$ for the servant equation. For a woman with a vector of personal characteristics $X$, the conditional probability of labor participation given she has a servant is $\operatorname{Pr}\left[e_{p}>-X \beta_{p} ; e_{s}>\right.$ $\left.-X \beta_{s} ; \rho\right] / \operatorname{Pr}\left[e_{s}>-X \beta_{s}\right]$. This probability can be obtained by numerical integration of the joint normal distribution for any given correlation coefficient $\rho$.
} 
participated in market work had a .008 higher conditional probability of hiring servants than women who did not participate.

\section{Children and Housework}

The previous section showed that the presence of young children in the family generally has a negative effect on female labor force participation. However, as pointed out in Section 1, this relationship need not always hold. If a woman hires a servant to do the housework, the extra burden generated by child care will be (to a large extent) borne by the servant. Heavy household duties then do not necessarily affect the woman's reservation wage for labor force participation. This is a particularly interesting implication to test since the negative effect of young children on female labor force participation has almost been a universal finding. ${ }^{14}$

Let $P^{*}$ and $S^{*}$ be the latent variables corresponding to the decision to enter the labor force and the decision to hire servants. Suppose the two decisions are related through the following model:

$$
\begin{aligned}
& P^{*}= \begin{cases}X \beta_{p 0}+e_{p}, & \text { if } S^{*}<0 ; \\
X \beta_{p 1}+e_{p}, & \text { if } S^{*} \geq 0 ;\end{cases} \\
& S^{*}= \begin{cases}X \beta_{s 0}+e_{s}, & \text { if } P^{*}<0 ; \\
X \beta_{s 1}+e_{s}, & \text { if } P^{*} \geq 0,\end{cases}
\end{aligned}
$$

In general the estimation of this model is computationally burdensome as it involves four inter-related double integrals. The model will be much simplified if $e_{p}$ and $e_{s}$ are assumed to be independent. ${ }^{15}$ With this assumption one can separate the sample into two depending on whether SERVANT $=0$ or SERVANT $=1$, and estimate a probit regression for participation status on each sub-sample. Similarly, one can separate the sample according to labor force participation status, and estimate the demand for servants on each sub-sample. These estimators are consistent but inefficient. Table 4 shows the estimation results.

\footnotetext{
14 See, for example, the various country studies in the January 1985 Supplement to the Journal of Labor Economics.

15 This assumption would be violated if there are important unmeasured personal characteristics that affect both the reservation wage for entering the labor force and the reservation price for hiring servants.
} 
Consider the participation equations first. The coefficient estimates in the second column are very close to those shown in Table $3 .{ }^{16}$ For women who did not hire servants, the market wage rate had a positive effect on participation while non-wage income had a negative effect. Moreover the presence of young children in the family significantly depressed labor force participation. The results for the sub-sample of women who had servants are quite different. The only statistically significant variable in column 3 is HINCOME. The coefficients on the children variables are insignificant and are of the "wrong" sign. ${ }^{17}$ Apparently the presence of young children did not deter labor market participation of those women who had market-procured domestic help.

A similar pattern can be observed for the pair of equations in the fourth and fifth columns of Table 4. For women who were in the labor force, the presence of young children significantly increased their probability of employing servants. For women who were not in the labor force, having a child between 0 and 6 years old did not significantly raise the probability of hiring servants. These results clearly illustrate the substitution between women's own time and market-procured help in the rearing of children.

\section{Concluding Remarks}

The household production model often assumes that household commodities have to be produced with household members' own time. But the definition of household commodities changes with the evolution of the market. In undeveloped economies, clothing and furniture may be considered household commodities in the sense that they have to be self-produced. In modern economies, such items are seldom made at home. The development of the market makes possible finer divisions of labor. The use of day-care centers, restaurants and washing machines are examples of substituting market-procured

\footnotetext{
16 This is hardly surprising as the probit equation in the second column used 97 percent of the observations in the entire sample.

17 The sub-sample of women with SERVANT=1 contains only 265 observations. The small sample size tends to make the standard errors relatively large. However I have also selected one thousand random samples of 265 observations and estimated a probit regression on each random sample. The resulting coefficient estimates were much closer to those in column 2 than to those in column 3 and were in general statistically significant. For example, the mean value of the coefficient for NKID3 was -.561 with an empirical standard deviation of .213. In 88 percent of the test runs, the variable NKID3 was significantly negative at the five percent level. Small sample size does not seem to be the reason for the statistically insignificant estimates in column 3.
} 
services for one's own time. The use of domestic servants is another example. While the proportion of households employing domestics is relatively small, all families use various market goods and services to save time. This paper demonstrates that the use of such services is an inseparable part of the female labor supply decision.

Nevertheless it is important to keep a proper perspective on the role of domestic servants on female labor supply. While the bivariate probit model in the paper estimates that the presence of a domestic servant in the family would raise the conditional probability of labor force participation from .46 to .69, the effect on the overall labor force participation rate need not be large. With only 3 percent of the households having live-in servants, the unconditional probability of labor force participation for all households was only .47. Even a doubling in the number of households with domestic servants would have increased the female labor force participation rate of the economy by less than one percentage point.

To the families concerned, however, the use of domestic servants can bring about substantial gains. The average monthly income for those employed women who had servants was $\$ 8,970$ (as opposed to $\$ 2,648$ for those who did not have servants). Their average monthly paycheck to their servants was $\$ 1,895$. After allowing for food and accommodation cost, the employers were still left with a comfortable margin. Whether the use of domestics is conspicuous consumption remains unclear; at least it is good investment. 


\section{References}

Bowen, William G. and T.A. Finegan. The Economics of Labor Force Participation. Princeton: Princeton University Press, 1969.

Cogan, John F. "Fixed Costs and Labor Supply." Econometrica 49 (July 1981): 945963.

Gronau, R. "The Effect of Children on the Housewife's Value of Time." Journal of Political Economy 81 (1973 Supplement): S168-S199.

Heckman, James J. "Effects of Child-Care Programs on Women's Work Effort." In T.W. Schultz, ed., Economics of the Family: Marriage, Children, and Human Capital. Chicago: University of Chicago Press, 1974.

—. "Sample Selection Bias as a Specification Error." Econometrica 47 (January 1979): 153-162.

Ho, Lok-sang, Liu, Pak-wai and Kit-chun Lam. International Labour Migration: The Case of Hong Kong. Hong Kong: Hong Kong Institute of Asia-Pacific Studies, 1991.

Horn, Pamela. The Rise and Fall of the Victorian Servant. New York: St. Martin's Press, 1975.

Katzman, David M. Seven Days a Week: Women and Domestic Service in Industrializing America. New York: Oxford University Press, 1978.

Killingsworth, Mark R. and James J. Heckman. "Female Labor Supply: A Survey." In O. Ashenfelter and R. Layard, eds., Handbook of Labor Economics, Vol. 1. Amsterdam: North-Holland, 1986.

Lui, Hon-Kwong and Wing Suen. "The Structure of the Female Earnings Gap in Hong Kong." Hong Kong Economic Papers (forthcoming 1993). 
Mincer, J. "Labor Force Participation of Married Women: A Study of Labor Supply." In National Bureau of Economic Research, Aspects of Labor Economics. Princeton: Princeton University Press, 1962.

Pollak, R.A. and M.L. Wachter. "The Relevance of Household Production Function and Its Implications for the Allocation of Time." Journal of Political Economy 83 (April 1975): 255-277.

Rosenzweig, Mark R. and Kenneth I. Wolpin. "Life-Cycle Labor Supply and Fertility: Causal Inference from Household Models." Journal of Political Economy 88 (April 1980): $328-348$.

Smith, James P. and Michael P. Ward. "Time-Series Growth in the Female Labor Force." Journal of Labor Economics 3 (1985 Supplement): S59-S90.

Stigler, George J. Domestic Servants in the United States: 1900-1940. New York: National Bureau of Economic Research, 1946.

Veblen, Thorstein. The Theory of the Leisure Class. New York: New American Library, 1953. 


\section{Table 1}

\section{Descriptive Sample Statistics}

\begin{tabular}{llcc}
\hline Variable & Description & Mean & Standard Deviation \\
\hline PARTICIPATE & In the labor force & .467 & .499 \\
SERVANT & Has at least one servant & .027 & .162 \\
EDUC & Years of education & 6.22 & 4.44 \\
AGE & Age & 42.3 & 12.9 \\
HINCOME & Household income less own employment earnings & 6448 & 7525 \\
NKID3 & No. of children between 0 and 3 years old & .234 & .504 \\
NKID6 & No. of children between 4 and 6 years old & .202 & .457 \\
NKID12 & No. of children between 7 and 12 years old & .421 & .742 \\
NKID18 & No. of children between 13 and 18 years old & .434 & .803 \\
NKIDBIG & No. of children more than 18 years old & .693 & 1.179 \\
\hline
\end{tabular}


Table 2

Contingency Table for PARTICIPATE and SERVANT

\begin{tabular}{|c|cc|c|}
\hline & PARTICIPATE $=0$ & PARTICIPATE $=1$ & TOTAL \\
\hline SERVANT $=0$ & 5118 & 4400 & 9518 \\
& $(52.3 \%)$ & $(45.0 \%)$ & $(97.3 \%)$ \\
SERVANT $=1$ & 95 & 170 & 265 \\
& $(1.0 \%)$ & $(1.7 \%)$ & $(2.7 \%)$ \\
\hline TOTAL & 5213 & 4570 & 9783 \\
& $(53.3 \%)$ & $(46.7 \%)$ & $(100 \%)$ \\
\hline
\end{tabular}


Table 3

Bivariate Probit Estimates

\begin{tabular}{|c|c|c|c|c|}
\hline Variable & PARTICIPATE & SERVANT & PARTICIPATE & SERVANT \\
\hline LNWAGE_HAT & $\begin{array}{c}.3845 \\
(.0344)\end{array}$ & $\begin{array}{c}.9131 \\
(.0656)\end{array}$ & - & - \\
\hline EDUC & - & - & $\begin{array}{l}-.0951 \\
(.0094)\end{array}$ & $\begin{array}{c}.0786 \\
(.0268)\end{array}$ \\
\hline EDUC_SQ & - & - & $\begin{array}{l}8.1764 \mathrm{e}-3 \\
(.6267 \mathrm{e}-3)\end{array}$ & $\begin{array}{c}3.2316 \mathrm{e}-3 \\
(1.4908 \mathrm{e}-3)\end{array}$ \\
\hline HINCOME & $\begin{array}{c}-.0183 \mathrm{e}-3 \\
(.0016 \mathrm{e}-3)\end{array}$ & $\begin{array}{c}.0345 \mathrm{e}-3 \\
(.0020 \mathrm{e}-3)\end{array}$ & $\begin{array}{c}-.0173 \mathrm{e}-3 \\
(.0016 \mathrm{e}-3)\end{array}$ & $\begin{array}{c}.0339 \mathrm{e}-3 \\
(.0021 \mathrm{e}-3)\end{array}$ \\
\hline AGE & $\begin{array}{c}.0160 \\
(.0088)\end{array}$ & $\begin{array}{l}-.0170 \\
(.0237)\end{array}$ & $\begin{array}{c}.0307 \\
(.0085)\end{array}$ & $\begin{array}{c}.0167 \\
(.0239)\end{array}$ \\
\hline AGE_SQ & $\begin{array}{l}-.4116 \mathrm{e}-3 \\
(.0957 \mathrm{e}-3)\end{array}$ & $\begin{array}{c}.5792 \mathrm{e}-3 \\
(.2409 \mathrm{e}-3)\end{array}$ & $\begin{array}{c}-.6948 \mathrm{e}-3 \\
(.0911 \mathrm{e}-3)\end{array}$ & $\begin{array}{c}.1099 \mathrm{e}-3 \\
(.2376 \mathrm{e}-3)\end{array}$ \\
\hline NKID3 & $\begin{array}{l}-.5325 \\
(.0308)\end{array}$ & $\begin{array}{c}.3231 \\
(.0874)\end{array}$ & $\begin{array}{l}-.5427 \\
(.0310)\end{array}$ & $\begin{array}{c}.3367 \\
(.0892)\end{array}$ \\
\hline NKID6 & $\begin{array}{l}-.3609 \\
(.0311)\end{array}$ & $\begin{array}{c}.3332 \\
(.0757)\end{array}$ & $\begin{array}{l}-.3662 \\
(.0313)\end{array}$ & $\begin{array}{c}.3448 \\
(.0770)\end{array}$ \\
\hline NKID12 & $\begin{array}{l}-.1101 \\
(.0189)\end{array}$ & $\begin{array}{c}.1661 \\
(.0536)\end{array}$ & $\begin{array}{l}-.1141 \\
(.0190)\end{array}$ & $\begin{array}{c}.1777 \\
(.0541)\end{array}$ \\
\hline NKID18 & $\begin{array}{c}.0328 \\
(.0178)\end{array}$ & $\begin{array}{l}-.1448 \\
(.0747)\end{array}$ & $\begin{array}{c}.0276 \\
(.0179)\end{array}$ & $\begin{array}{l}-.1396 \\
(.0754)\end{array}$ \\
\hline NKIDBIG & $\begin{array}{l}-.0651 \\
(.0144)\end{array}$ & $\begin{array}{l}-.1631 \\
(.0524)\end{array}$ & $\begin{array}{l}-.0791 \\
(.0145)\end{array}$ & $\begin{array}{l}-.1485 \\
(.0523)\end{array}$ \\
\hline CONSTANT & $\begin{array}{l}-.8490 \\
(.2082)\end{array}$ & $\begin{array}{c}-6.0990 \\
(.5564)\end{array}$ & $\begin{array}{c}.4869 \\
(.1907)\end{array}$ & $\begin{array}{c}-4.3498 \\
(.5772)\end{array}$ \\
\hline RHO & $\begin{array}{l}.211 \\
(.043\end{array}$ & & \multicolumn{2}{|c|}{.2228} \\
\hline
\end{tabular}

Standard errors are in parentheses. 


\section{Table 4}

Probit Regressions on Sub-Samples

\begin{tabular}{|c|c|c|c|c|}
\hline Variable & $\begin{array}{l}\text { Dep. Var.: PA } \\
\text { SERVANT }=0\end{array}$ & $\begin{array}{l}\text { ARTICIPATE } \\
\text { SERVANT }=1\end{array}$ & $\begin{array}{r}\text { Dep. Var.: } \\
\text { PARTICIPATE }=0\end{array}$ & $\begin{array}{l}\text { SERVANT } \\
\text { PARTICIPATE }=1\end{array}$ \\
\hline LNWAGE_HAT & $\begin{array}{l}.3533 \\
(.0372)\end{array}$ & $\begin{array}{c}.0907 \\
(.1615)\end{array}$ & $\begin{array}{c}.9588 \\
(.0959)\end{array}$ & $\begin{array}{c}.8169 \\
(.0800)\end{array}$ \\
\hline HINCOME & $\begin{array}{l}-.0250 \mathrm{e}-3 \\
(.0024 \mathrm{e}-3)\end{array}$ & $\begin{array}{l}-.0113 \mathrm{e}-3 \\
(.0045 \mathrm{e}-3)\end{array}$ & $\begin{array}{c}.0351 \mathrm{e}-3 \\
(.0031 \mathrm{e}-3)\end{array}$ & $\begin{array}{c}.0413 \mathrm{e}-3 \\
(.0036 \mathrm{e}-3)\end{array}$ \\
\hline AGE & $\begin{array}{l}.0150 \\
(.0090)\end{array}$ & $\begin{array}{l}.8100 \mathrm{e}-3 \\
(.0719)\end{array}$ & $\begin{array}{l}-.0120 \\
(.0338)\end{array}$ & $\begin{array}{c}.0022 \\
(.0374)\end{array}$ \\
\hline AGE_SQ & $\begin{array}{l}-.4144 \mathrm{e}-3 \\
(.0997 \mathrm{e}-3)\end{array}$ & $\begin{array}{l}-.4039 \mathrm{e}-3 \\
(.7428 \mathrm{e}-3)\end{array}$ & $\begin{array}{c}.5803 \mathrm{e}-3 \\
(.3297 \mathrm{e}-3)\end{array}$ & $\begin{array}{c}.3417 \mathrm{e}-3 \\
(.4306 \mathrm{e}-3)\end{array}$ \\
\hline NKID3 & $\begin{array}{l}-.5731 \\
(.0326)\end{array}$ & $\begin{array}{c}.1682 \\
(.2158)\end{array}$ & $\begin{array}{l}-.0110 \\
(.1439)\end{array}$ & $\begin{array}{c}.6313 \\
(.0838)\end{array}$ \\
\hline NKID6 & $\begin{array}{l}-.3925 \\
(.0321)\end{array}$ & $\begin{array}{c}.0893 \\
(.1776)\end{array}$ & $\begin{array}{c}.1546 \\
(.1274)\end{array}$ & $\begin{array}{c}.5637 \\
(.0849)\end{array}$ \\
\hline NKID12 & $\begin{array}{l}-.1128 \\
(.0198)\end{array}$ & $\begin{array}{l}-.1448 \\
(.1276)\end{array}$ & $\begin{array}{l}.2302 \\
(.0771)\end{array}$ & $\begin{array}{c}.1392 \\
(.0657)\end{array}$ \\
\hline NKID18 & $\begin{array}{c}.0332 \\
(.0183)\end{array}$ & $\begin{array}{l}.0252 \\
(.1985)\end{array}$ & $\begin{array}{l}-.1637 \\
(.1061)\end{array}$ & $\begin{array}{l}-.1204 \\
(.0896)\end{array}$ \\
\hline NKIDBIG & $\begin{array}{l}-.0550 \\
(.0148)\end{array}$ & $\begin{array}{l}-.2739 \\
(.1885)\end{array}$ & $\begin{array}{l}-.1006 \\
(.0611)\end{array}$ & $\begin{array}{l}-.3892 \\
(.1381)\end{array}$ \\
\hline CONSTANT & $\begin{array}{l}-.6630 \\
(.2170)\end{array}$ & $\begin{array}{c}.9782 \\
(1.6774)\end{array}$ & $\begin{array}{c}-6.5928 \\
(.8933)\end{array}$ & $\begin{array}{l}-6.1584 \\
(.7318)\end{array}$ \\
\hline
\end{tabular}

Standard errors are in parentheses. 


\title{
MARKET-PROCURED HOUSEWORK: THE DEMAND FOR DOMESTIC SERVANTS AND FEMALE LABOR SUPPLY
}

\author{
Wing Suen* \\ University of Hong Kong
}

(January 1994)

Abstract. Domestic servants and a woman's own time are substitutes in the household production process. The demand for servants increases with the woman's market wage, her non-wage income, and the presence of young children in the family. A bivariate probit model using data from Hong Kong suggests that women who participate in the labor force have a .008 higher probability of having servants than women who are not in the labor force. Conversely, women who have servants have a .22 higher probability of labor force participation than woman with no servants. In households that use marketprocured domestic help, the presence of young children is found to have no negative effect on female labor force participation.

\footnotetext{
* Doug Allen, Leigh Anderson, Yoram Barzel, Steve Ching, Chris Hall, Frank Rusco, Alan Siu, Richard Wong, and a referee offered useful help. Remaining shortcomings are mine.
} 
(a) $\mathbf{w}=\mathbf{P} / \mathbf{D}$

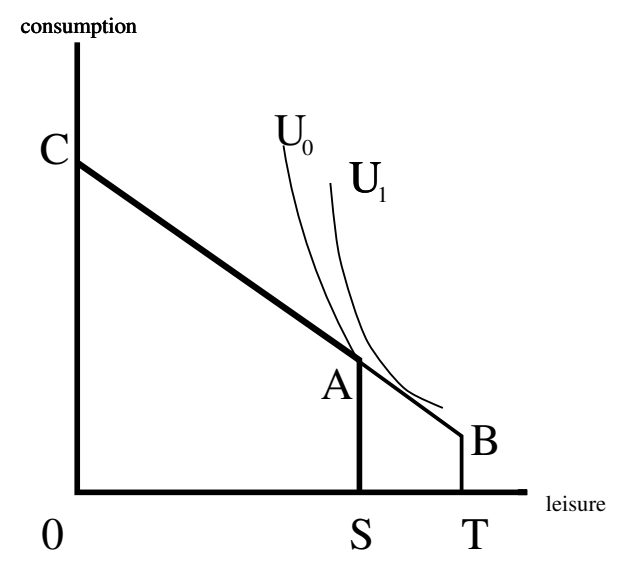

(b) $\quad w>P / D$

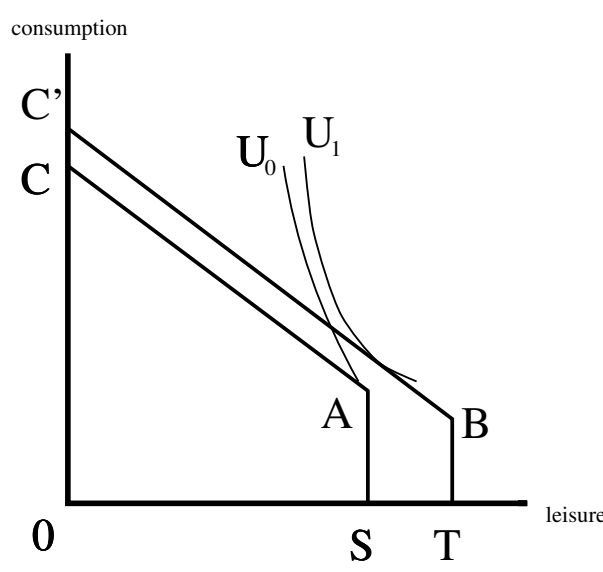

(c) $\mathbf{w}<$ P/D

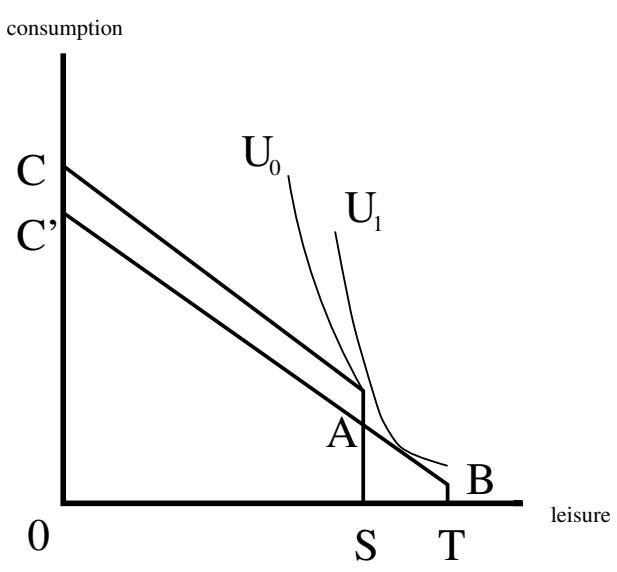

Figure 1: Effect of domestic help on the consumption-leisure choice of women who are otherwise not in the labor force 
(a) $\quad \mathbf{w}=\mathbf{P} / \mathbf{D}$

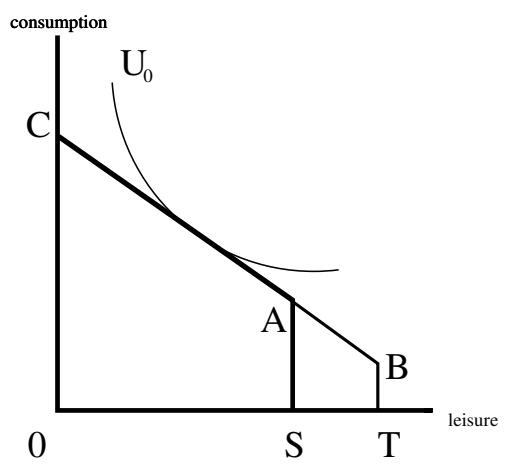

(b) $\mathbf{w}>\mathbf{P} / \mathbf{D}$

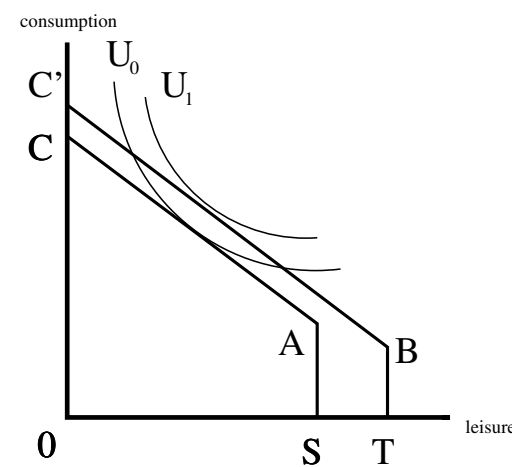

(c) $\quad \mathbf{W}<\mathbf{P} / \mathbf{D}$

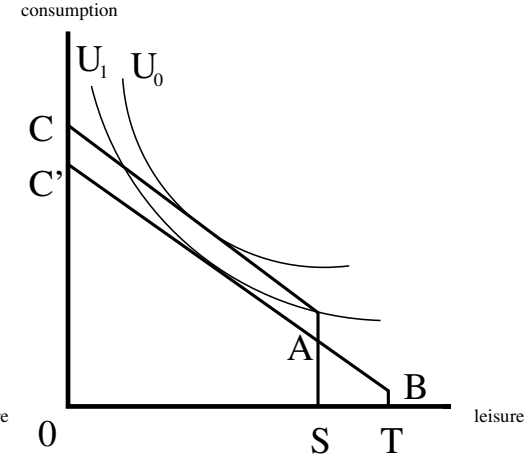

Figure 2: Effect of domestic help on the consumption-leisure choice of women who are otherwise in the labor force 